\title{
STUDY OF THE INTERACTIONS BETWEEN COPPER(II) ACETATE MONOHYDRATE AND OROTIC ACID AND OROTATE LIGANDS
}

\author{
GLORIA V. SEGUEL*, BERNABÉ L. RIVAS, CÉSAR PAREDES
}

Facultad de Ciencias Químicas, Universidad de Concepción, Casilla 160-C, Concepción, Chile. (Received: December 21, 2009 - Accepted: July 26, 2010)

\begin{abstract}
Different complexes by reacting copper(II) acetate monohydrate with orotic acid and orotate as ligands were prepared. These compounds were characterized by elemental analysis, spectroscopy, and thermal analysis. It is suggested that in both compounds, the $\mathrm{Cu}_{2}\left(\mathrm{acetate}_{4}\right.$ suffers the break of both acetate groups by a substitution of orotic or orotate ligands, increasing the $\mathrm{Cu}-\mathrm{Cu}$ distance. It was corroborated by the magnetic moment values of 1.65 and $1.82 \mathrm{~B} . \mathrm{M}$ for these compounds.

The anion orotato(-1) coordinates through the carboxylic acid and the orotic acid by the oxygen from exocyclic $\mathrm{C}=\mathrm{O}$.

Semiempirical PM3 calculations for both compounds were also carried out.
\end{abstract}

Keywords : Copper(II) acetate, metal acetate, orotic acid, semi-empirical calculations.

\section{INTRODUCTION}

Metal orotates and acetates are widely used in medicine field to incorporate metals to the organism to decrease the absence of these in some sickness. The incorporation of transition metal ions to form coordination compounds with orotates, the redox, optic, and magnetic properties surely will change $\mathrm{e}^{1,2}$.

Besides, it is biologically important as orotic acid (see figure 1) and it has also an interesting coordination chemistry. It may coordinate through the carboxyl group, the two oxygens from carbonyl, and the two nitrogen atoms of the pyrimidine ring.

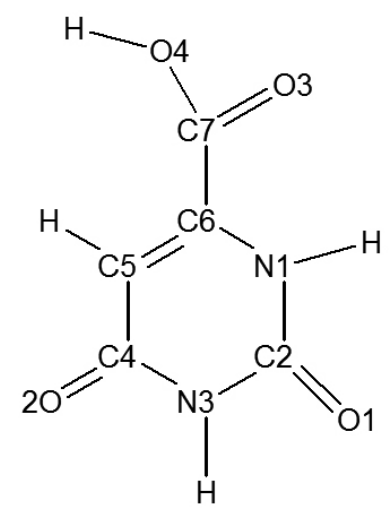

Fig.1. Structure of orotic acid.

Between $\mathrm{pH} 3$ and 9 , orotic acid is present in aqueous solutions mainly as orotate anion, the carboxylic acid group has $\mathrm{pK}=2.07^{3}$. At acid $\mathrm{pH}$ it coordinates through carboxylic acid group. The most potential coordination sites in the range 5-9 are the carboxylic oxygen and the adjacent pyrimidine nitrogen atom (N1). In order to evaluate the pharmaceutical properties, many metal complexes of orotic acid have been studied ${ }^{4-7}$.

Transition metal complexes where the orotate(1-) ligand shows a mono coordination through the carboxylic acid group ${ }^{4}$ and for orotate(2-), where the main coordination site corresponds to adjacent nitrogen have been reported. When they coordinate a metal ion, the complexing ability of the exocyclic carbonyl oxygen is strongly enhanced ${ }^{5}$. Corroborating this theory, polynuclear compounds have been reported, where one of the oxygen coming from exocyclic carbonyl group coordinates with a neighbor metal ion as polymer complex- $\mathrm{Cu}\left[\left(\mathrm{C}_{5} \mathrm{H}_{2} \mathrm{~N}_{2} \mathrm{O}_{4}\right) \mathrm{Cu}\left(\mathrm{H}_{2} \mathrm{O}\right)_{2}\right]_{n}{ }^{6,7}$.

In a non-aqueous neutral medium has been reported that the coordination is produced through exocyclic oxygen coming from carbonyl group $C(4)=O$ (1).
Copper acetate monohydrate can react with monomeric ligands forming an adduct by replacing the water molecules. In these compounds the $\mathrm{Cu}-\mathrm{Cu}$ distances and the magnetic moments change slightly ${ }^{7-11}$. It is also possible to lose an acetate group to allow the coordination of other ligands or even change de coordination of the acetate group to monodentate coordination with the break of the $\mathrm{Cu}_{2}$ (acetate) $)_{4}$ unit, as it occurs with the imidazole ligand ${ }^{12-15}$. With polymeric ligands interact loosing one or two water molecules but also an acetate group to coordinate with the polymer as occur with poly(DL-aspartic acid) ${ }^{16-17}$.

The goal of the current manuscript is the study of the interactions of orotic acid and orotate anion with copper(II) acetate monohydrate.

\section{EXPERIMENTAL}

Materials: $\mathrm{Cu}_{2}\left(\mathrm{CH}_{3} \mathrm{COO}\right)_{4} \cdot 2 \mathrm{H}_{2} \mathrm{O}$ p.a (Merck), sodium orotate (Aldrich), orotic acid (Aldrich) were used without further purification.

Preparation of complex

$\mathrm{Cu}_{2}$ (acetate $)_{2}\left(\mathrm{H}_{2} \mathrm{OR}\right)_{2}, \quad\left(\mathrm{H}_{2} \mathrm{OR}=\operatorname{orotate}(1-)\right)$

This compound was synthesized by reacting under stirring aqueous solutions of sodium orotate and $\mathrm{Cu}_{2}(\text { acetate })_{4} \cdot 2 \mathrm{H}_{2} \mathrm{O}$, at $\mathrm{pH}=3$, controlling the $\mathrm{pH}$ by $\mathrm{CH}_{3} \mathrm{COOH}$. It was obtained a green precipitate, which was filtered and washed with distilled water, and dried at $60^{\circ} \mathrm{C}$ up to constant weight.

Elemental analysis: (Found: $\mathrm{Cu}: 20.2 \% \mathrm{~N}: 10.1 \%$, C: $28.1 \%, \mathrm{H}: 2.2 \%$, Calcd.: $\mathrm{Cu}: 22.8 \%$, N: $10.1 \%$. C: $30.3 \%, \mathrm{H}: 2.2 \%)$.

$\mathrm{Cu}_{2}$ (acetate $)_{4}\left(\mathrm{H}_{3} \mathrm{OR}\right)_{4},\left(\mathrm{H}_{3} \mathrm{OR}=\right.$ orotic acid $)$

It was obtained by reacting orotic acid with $\mathrm{Cu}_{2}$ (acetate) $)_{4} \cdot 2 \mathrm{H}_{2} \mathrm{O}$ under refluxing in neutral medium using ethyl acetate as solvent. The precipitate was washed with the same solvent, filtered and dried at $60^{\circ} \mathrm{C}$ up to constant weight.

(Found: $\mathrm{Cu}: 13.8 \%$, N: $11.6 \%$, C: $33.0 \%$, H: $2.0 \%$, Calcd.: Cu: $12.9 \%$, N: $11.4 \%$. C: $34.2 \%$, H: $2.5 \%$ ).

The coordination compounds are insoluble in water and in common organic solvents as acetone, acetonitrile and ethanol.

Measurements: Elemental analysis were obtained using a Series II CHNS 10 analyzer 2400 Perkin Elmer. $\mathrm{Cu}(\mathrm{II})$ was analyzed by atomic absorption spectrometry (AAS) with a Perkin Elmer model 3100. The FT IR spectra of the samples were recorded on a Nicolet Nexus spectrophotometer. The diffuse reflectance spectra were measured on a Perkin Elmer Lambda 20 spectrophotometer coupled to Labsphere reflectance diffuse attachment and Spectralon as reference. Thermogravimetric analyses of the polychelates were performed with a TA Instrument Q50 analyzer.

Quantum Chemical Calculations: PM3 semi-empirical calculations were carried out using a MOPAC program that is included in HyperChem 7. The compounds were created graphically with support of the HyperChem Program. It was optimized by molecular mechanical and subsequently by PM3 calculation method. 


\section{RESULTS AND DISCUSSION}

The $\lambda_{\max }$ values of the absorption bands and the effective magnetic moments of the complexes are summarized in Table 1.

Both compounds show a similar spectrum to the copper(II) acetate monohydrate, absorption bands near to $700 \mathrm{~nm}$ and $400 \mathrm{~nm}$. The last one has been reported as a characteristic band to the acetates with bridge coordination type ${ }^{16-19}$.

The magnetic moments for the compounds I and II 1.82 and 1.65.M.B respectively are higher than that 1.4 M.B reported for coper(II) acetate monohydrate ${ }^{20}$.

Table 1. Properties of the complexes

\begin{tabular}{lcccc}
\hline Complex & $\lambda(\mathrm{nm})$ & $\mu_{\text {eff }}(\mathrm{B} . \mathrm{M}$. $)$ & $\mathrm{Tmax}\left({ }^{\circ} \mathrm{C}\right)$ & Group \\
\hline $\mathrm{Cu}_{2}(\text { acetate })_{2}\left(\mathrm{H}_{2} \mathrm{OR}\right)_{2}$ (I) & 385 & 1.82 & 275.88 & acetate \\
& 705 & & 286.60 & acetate \\
& & & 355.52 & orotate \\
& & & 412.25 & orotate \\
$\mathrm{Cu}_{2}$ (acetate $)_{4}\left(\mathrm{H}_{3} \mathrm{OR}\right)_{4}$ (II) & 441 & 1.65 & 264.81 & acetate \\
& 700 & & 327.62 & orotic acid \\
\hline
\end{tabular}

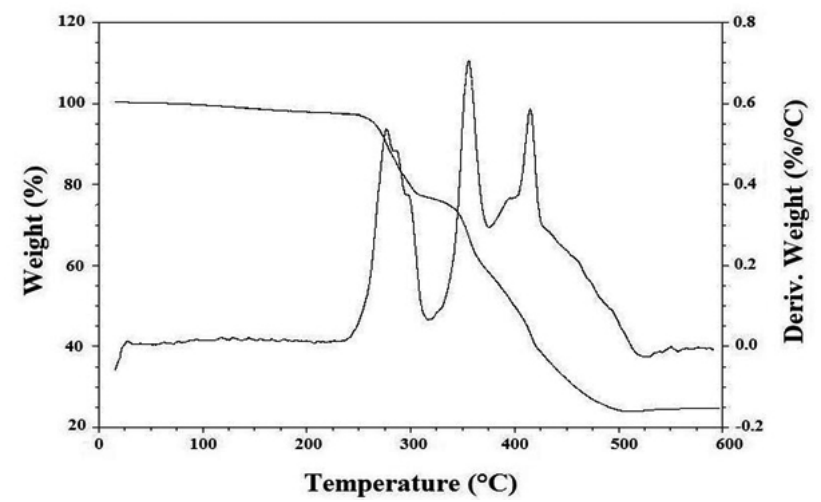

Fig. 2. TGA and DTG curves of $\mathrm{Cu}_{2}$ (acetate $)_{2}\left(\mathrm{H}_{2} \mathrm{OR}\right)_{2}$. Heating rate: $20^{\circ} \mathrm{C} \mathrm{min}^{-1}$ under $\mathrm{N}_{2}$ atmosphere.

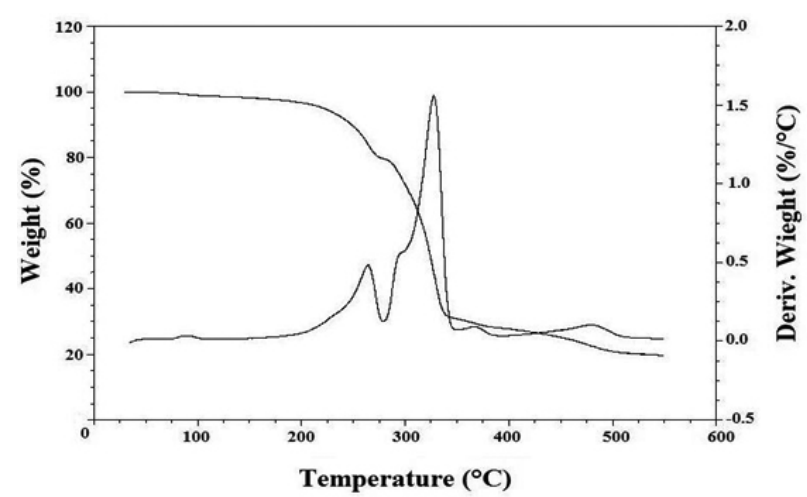

Fig. 3 TGA and DTG curves of $\mathrm{Cu}_{2}(\text { acetate })_{4}\left(\mathrm{H}_{3} \mathrm{OR}\right)_{4}$ Heating rate: $20^{\circ} \mathrm{C}$ $\min ^{-1}$ under $\mathrm{N}_{2}$ atmosphere.

TGA-DTG of $\mathrm{Cu}_{2}$ (acetate $)_{2}\left(\mathrm{H}_{2} \mathrm{OR}\right)_{2}$ show two maxima between 250$300^{\circ} \mathrm{C}$ which can be attributed to loss of acetate ligands and other two maxima peaks between $350-450^{\circ} \mathrm{C}$ are due to orotate weight loss ${ }^{21}$ (see Figure 2).

TGA-DTG of $\mathrm{Cu}_{2}$ (acetate) ${ }_{4}\left(\mathrm{H}_{3} \mathrm{OR}\right)$ show two maxima at $265^{\circ} \mathrm{C}$ and at $328^{\circ} \mathrm{C}$ attributed to weight loss of acetate and orotic acid ligands respectively (see Figure 3).

TGA-DTG (see table 1, Figures 2 and 3) did show not for both compounds the weight loss of water molecules, therefore, it is suggested that the coordination of orotate and orotic acid groups displace the water molecules coordinated to $\mathrm{Cu}(\mathrm{II})^{22}$.

According to elemental analysis and TGA, the following reactions can be suggested:

$\mathrm{Cu}_{2}\left(\mathrm{CH}_{3} \mathrm{COO}\right)_{4} \cdot 2 \mathrm{H}_{2} \mathrm{O}+2 \mathrm{H}_{2} \mathrm{OR}^{1-}=\mathrm{Cu}_{2}\left(\mathrm{CH}_{3} \mathrm{COO}\right)_{2}\left(\mathrm{H}_{2} \mathrm{OR}\right)_{2}+$ $2 \mathrm{H}_{2} \mathrm{O}+2 \mathrm{CH}_{3} \mathrm{COO}^{-}$

$\mathrm{Cu}(\mathrm{II})$ acetate monohydrate react with orotate ion loosing two water molecules and two acetate groups. $\mathrm{Cu}$ (II) ions keep bound by two bridge acetate groups and the orotate ions coordinate through carboxylic acid group with each $\mathrm{Cu}(\mathrm{II})$ ion.

$$
\mathrm{Cu}_{2}\left(\mathrm{CH}_{3} \mathrm{COO}\right)_{4} \cdot 2 \mathrm{H}_{2} \mathrm{O}+4 \mathrm{H}_{3} \mathrm{OR}=\mathrm{Cu}_{2}\left(\mathrm{CH}_{3} \mathrm{COO}\right)_{4}\left(\mathrm{H}_{3} \mathrm{OR}\right)_{4}+2 \mathrm{H}_{2} \mathrm{O}
$$

In neutral medium the orotic acid coordinates through an oxygen coming from $\mathrm{C}=\mathrm{O}$ group loosing two water-molecules. To replace two orotic acid, each water-molecule, the bridge coordination of two acetate groups which keep coordinated to $\mathrm{Cu}(\mathrm{II})$ ions through a monodentate coordination.

Semiempirical calculations PM3, AM1, and CNDO of reported orotic charge data of orotic acid indicate that the oxygen from $\mathrm{C}(2)=\mathrm{O}$ has the highest net charge (see Table 2) ${ }^{23,24}$. Therefore, it is possible suggest that the orotic acid coordinates with $\mathrm{Cu}$ (II) ion through this oxygen as it was reported for the complex obtained from $\mathrm{Zn}(\mathrm{II})$ acetate and orotic acid ${ }^{23}$.

Table 2. PM3 calculations of net charge of orotic acid.

\begin{tabular}{lc}
\hline Atom & net charge \\
\hline $\mathrm{N}(1)$ & 0.081 \\
$\mathrm{O}(11)$ & -0.374 \\
$\mathrm{~N}(3)$ & -0.004 \\
$\mathrm{O}(12)$ & -0.328 \\
$\mathrm{O}(9)$ & -0.298 \\
$\mathrm{O}(8)$ & -0.252 \\
\hline
\end{tabular}

Table 3. Some FT-IR characteristic absorption bands of $\mathrm{H}_{3} \mathrm{OR}, \mathrm{H}_{2} \mathrm{OR}$, $\mathrm{Cu}_{2}$ (acetate) $)_{2}\left(\mathrm{H}_{2} \mathrm{OR}\right)_{2}$, and $\mathrm{Cu}_{2}$ (acetate $)_{4}\left(\mathrm{H}_{3} \mathrm{OR}\right)_{4}$.

\begin{tabular}{lcccc}
\hline & $\mathrm{H}_{3} \mathrm{OR}$ & $\mathrm{H}_{2} \mathrm{OR}^{-}$ & $\mathrm{Cu}_{2}$ (acetate $)_{2}\left(\mathrm{H}_{2} \mathrm{OR}\right)_{2}$ & $\mathrm{Cu}_{2}$ (acetate $)_{4}\left(\mathrm{H}_{3} \mathrm{OR}\right)_{4}$ \\
\hline$v\left(\mathrm{O}-\mathrm{H}_{\text {acid }}\right)$ & $3515 \mathrm{~s}$ & & & $3407 \mathrm{w}$ \\
$v(\mathrm{~N}-\mathrm{H})$ & $3168 \mathrm{~s}$ & $3211 \mathrm{~s}$ & $3209 \mathrm{~s}$ & $3159 \mathrm{~s}$ \\
& $3111 \mathrm{~s}$ & & & $2500 \mathrm{w}$ \\
$v\left(\mathrm{O}-\mathrm{H}_{\text {acid }}\right)$ & $2500 \mathrm{w}$ & & & $1694 \mathrm{vs}$ \\
$v\left(\mathrm{C}=\mathrm{O}_{\text {acid }}\right)+$ & $1700 \mathrm{vs}$ & $1744 \mathrm{vs}$ & $1726 \mathrm{~s}$ & $1648 \mathrm{vs}$ \\
$v\left(\mathrm{C}_{2}=\mathrm{O}\right)$ & & & & \\
$v\left(\mathrm{C}_{4}=\mathrm{O}\right)+$ & $1666 \mathrm{vs}$ & $1694 \mathrm{vs}$ & $1659 \mathrm{vs}$ & $1515 \mathrm{~ms}$ \\
$v(\mathrm{C}=\mathrm{C})$ & & & & $1436 \mathrm{~s}$ \\
$v(\mathrm{COO}-) \mathrm{a}$ & $1513 \mathrm{~ms}$ & $1492 \mathrm{~ms}$ & $1481 \mathrm{~ms}$ & $1326 \mathrm{~ms}$ \\
$v(\mathrm{~N}-\mathrm{H})$ & $1430 \mathrm{~ms}$ & $1426 \mathrm{~s}$ & $1421 \mathrm{~ms}$ & \\
$v(\mathrm{COO}-) \mathrm{s}$ & 1337 & $1380 \mathrm{vs}$ & $1381 \mathrm{~s}$ & \\
& & & &
\end{tabular}

$v\left(\mathrm{COO}^{-}\right)$a, anty-symmetrical vibration , $v\left(\mathrm{COO}^{-}\right)$s, symmetrical vibration

Table 3 shows some characteristic absorption bands of functional groups of orotic acid, orotate, and the $\mathrm{Cu}$ (II) complexes according to the assignment made by Maitralis et al. ${ }^{3}$.

$\mathrm{Cu}_{2}$ (acetate) $)_{2}\left(\mathrm{H}_{2} \mathrm{OR}\right)_{2}$ did not show the absorption band at $2500 \mathrm{~cm}^{-1}$ corresponding to the stretching vibration $v(\mathrm{O}-\mathrm{H})$ of carboxylic acid, due to intermolecular interactions ocurr between the carboxylic acids indicating the coordination through this group. The presence of the absorption band at 3209 $\mathrm{cm}^{-1}$ assigned to stretching vibration $\mathrm{v}(\mathrm{N}-\mathrm{H})$ implies no shift in the stretching vibration (expected at $3211 \mathrm{~cm}^{-1}$ ) and corroborates that this group is not involved in the coordination. The asymmetric stretching vibration of $\mathrm{H}_{2} \mathrm{OR}^{-}$is observed at $1492 \mathrm{~cm}^{-1}$ and it is shifted at $1481 \mathrm{~cm}^{-1}$ in the complex due to the effect of coordination, but the symmetric stretching vibration $v\left(\mathrm{COO}^{-}\right) \mathrm{s}$ does not suffer change. At $1585 \mathrm{~cm}^{-1}$ is observed a shoulder which can be assigned to stretching vibration $\mathrm{v}\left(\mathrm{COO}^{-}\right)$a from bridge acetate groups.

The spectrum of $\mathrm{Cu}_{2}$ (acetate $)_{4}\left(\mathrm{H}_{3} \mathrm{OR}\right)_{4}$ shows the absorption band at 2500 $\mathrm{cm}^{-1}$ corresponding to the stretching vibration $\mathrm{v}(\mathrm{O}-\mathrm{H})$ of carboxylic acid, due to intermolecular interactions of carboxylic acids and there is not change on the $v(\mathrm{~N}-\mathrm{H})$. In this compound it is also observed a shoulder at $1585 \mathrm{~cm}^{-1}$ attributed 
to $v\left(\mathrm{COO}^{-}\right)$of bridge acetate groups.

The FT IR spectrum of orotic acid shows at region of stretching vibration $v(\mathrm{C}=\mathrm{O})$ two bands at 1700 and $1666 \mathrm{~cm}^{-1}$ which are assigned for other authors to $v\left(\mathrm{C}=\mathrm{O}_{\text {aid }}\right)+v(\mathrm{C}(2)=\mathrm{O})$ and $v(\mathrm{C}(4)=\mathrm{O})+v(\mathrm{C}=\mathrm{C})$, respectively ${ }^{3}$.

Based on $\mathrm{PM} 3$ calculations of vibration spectrum from the compound $\mathrm{Cu}_{2}\left(\mathrm{CH}_{3} \mathrm{COO}\right)_{4}\left(\mathrm{H}_{3} \mathrm{Or}\right)_{4}$ the absorption band at $1694 \mathrm{~cm}^{-1}$ attributed to $v(\mathrm{C}(4)=\mathrm{O})$ and that at $1648 \mathrm{~cm}^{-1}$ to $v(\mathrm{C}(2)=\mathrm{O})($ see Table 4$)$.

Table 4. Calculations of some stretching vibrations of $\mathrm{H}_{3} \mathrm{Or}$ and $\mathrm{Cu}_{2}\left(\mathrm{CH}_{3} \mathrm{COO}\right)_{4}\left(\mathrm{H}_{3} \mathrm{Or}\right)_{4}{ }^{*}$

\begin{tabular}{lccccc}
\hline$v\left(\mathrm{~cm}^{-1}\right)$ & \multicolumn{2}{c}{$\mathrm{H}_{3} \mathrm{Or}$} & \multicolumn{2}{c}{$\mathrm{Cuk}_{2}\left(\mathrm{CH}_{3} \mathrm{COO}\right)_{4}\left(\mathrm{H}_{3} \mathrm{Or}\right)_{4}$} \\
\hline & Exp. & Calc. & & Exp. & Calc. \\
\cline { 2 - 6 }$v(\mathrm{C}(3)=\mathrm{O})$. & 1739 & 1978 & & & 1982 \\
$v(\mathrm{C}(4)=\mathrm{O})$. & 1699 & 1938 & & 1694 & 1947 \\
$v(\mathrm{C}(2)=\mathrm{O})$. & 1660 & 1897 & 1648 & 1840 \\
\hline
\end{tabular}

*PM3 calculations have been not corrected.

According to the experimental data, the structures of both compounds and the orotate anion(-1) were calculated by semi-empirical PM3 method and these were compared with the reported date of the $\mathrm{Cu}(\mathrm{II})$ acetate monohydrate (see Fig. 4) and the orotic acid.

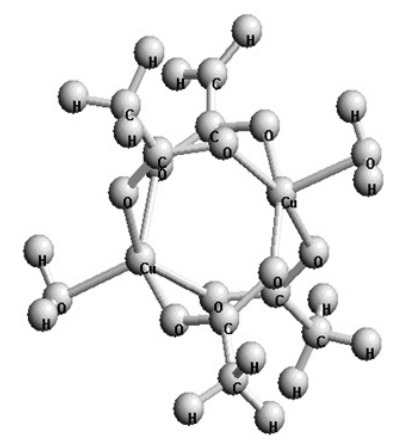

Fig. 4 Structure of $\mathrm{Cu}_{2}$ (acetate) $)_{4} \cdot 2 \mathrm{H}_{2} \mathrm{O}$

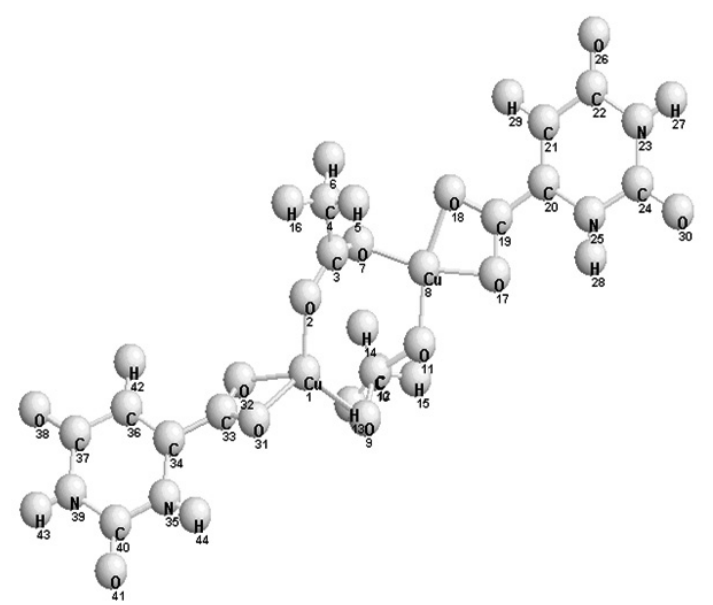

Fig. 5. $\mathrm{PM} 3$ structure of $\mathrm{Cu}_{2}\left(\mathrm{CH}_{3} \mathrm{COO}\right)_{2}\left(\mathrm{H}_{2} \mathrm{OR}\right)_{2}$

For $\mathrm{Cu}_{2}$ (acetate $)_{2}\left(\mathrm{H}_{2} \mathrm{OR}\right)_{2}$ is suggested a structure where the $\mathrm{Cu}$ (II) ions are bound to two bridge acetate groups and the orotate anion coordinates through the carboxylic groups with a bidentate coordination (see Figure 5).
Table 5. Selected PM3 structural parameters of $\mathrm{Cu}_{2}\left(\mathrm{CH}_{3} \mathrm{COO}\right)_{4} \cdot 2 \mathrm{H}_{2} \mathrm{O}$, $\mathrm{H}_{2} \mathrm{OR}^{-}, \mathrm{Cu}_{2}$ (acetate $)_{2}\left(\mathrm{H}_{2} \mathrm{OR}\right)_{2}$

\begin{tabular}{|c|c|c|c|}
\hline Parameter & $\mathrm{Cu}_{2}$ (acetate $)_{2}\left(\mathrm{H}_{2} \mathrm{OR}\right)_{2}$ & $\mathrm{Cu}_{2}\left(\mathrm{CH}_{3} \mathrm{COO}\right)_{4} \cdot 2 \mathrm{H}_{2} \mathrm{O}$ & $\mathrm{H}_{2} \mathrm{OR}^{-}$ \\
\hline \multicolumn{4}{|l|}{ Bond length $\left(A^{\circ}\right)$} \\
\hline $\mathrm{Cu}(1)-\mathrm{Cu}(8)$ & 3.957 & 3.38 & \\
\hline $\mathrm{Cu}(1)-\mathrm{O}(2)$ & 1.930 & 2.013 & \\
\hline $\mathrm{Cu}(1)-\mathrm{O}(9)$ & 1.927 & 2.018 & \\
\hline $\mathrm{Cu}(1)-\mathrm{O}(31)$ & 1.919 & & \\
\hline $\mathrm{Cu}(1)-\mathrm{O}(32)$ & 1.955 & & \\
\hline $\mathrm{C}(3)-\mathrm{O}(2)$ & 1.250 & 1.25 & \\
\hline $\mathrm{C}(3)-\mathrm{O}(7)$ & 1.368 & 1.34 & \\
\hline $\mathrm{C}(33)-\mathrm{C}(34)$ & 1.489 & & 1.562 \\
\hline $\mathrm{C}(33)-\mathrm{O}(32)$ & 1.286 & & 1.243 \\
\hline $\mathrm{C}(33)-\mathrm{O}(31)$ & 1.300 & & 1.253 \\
\hline $\mathrm{C}(37)-\mathrm{C}(38)$ & 1.224 & & 1.228 \\
\hline$C(40)-C(41)$ & 1.220 & & 1.235 \\
\hline \multicolumn{4}{|l|}{ Bond angle $\left({ }^{\circ}\right)$} \\
\hline $\mathrm{O}(31)-\mathrm{C}(33)-\mathrm{O}(32)$ & 122 & 130 & \\
\hline \multicolumn{4}{|l|}{ Net charge atom $\left(N^{\circ}\right)$} \\
\hline $\mathrm{Cu}(1)$ & -0.307 & -0.212 & \\
\hline $\mathrm{O}(2)$ & -0.098 & -0.241 & \\
\hline$O(9)$ & -0.135 & -0.251 & \\
\hline$C(10)$ & 0.363 & 0.343 & \\
\hline $\mathrm{O}(11)$ & -0.183 & & \\
\hline $\mathrm{O}(32)$ & -0.282 & & -0.609 \\
\hline $\mathrm{C}(33)$ & 0.399 & & 0.467 \\
\hline
\end{tabular}

$\mathrm{Cu}-\mathrm{Cu}$ distance in the compound $\mathrm{Cu}_{2}$ (acetate $)_{2}\left(\mathrm{H}_{2} \mathrm{OR}\right)_{2}$ is $3.957 \mathrm{~A}^{\circ}$, which is higher than that reported value $3.38 \mathrm{~A}^{\circ}$ for $\mathrm{Cu}_{2}\left(\mathrm{CH}_{3} \mathrm{COO}\right)_{4} \cdot 2 \mathrm{H}_{2} \mathrm{O}$, calculated with the same method ${ }^{16}$, but the $\mathrm{Cu}-\mathrm{O}$ distances did not suffer important change (see Table 5). In the complex, the distance $\mathrm{C}(33)-\mathrm{C}(34) 1.489 \mathrm{~A}^{\circ}$ is lower than that free orotate anion $1.562 \mathrm{~A}^{\circ}$. Respect to the net charge, important changes are produced in the distribution due to the effect of the coordination of the orotate ligand.

For the compound $\mathrm{Cu}_{2}$ (acetate $)_{4}\left(\mathrm{H}_{3} \mathrm{OR}\right)_{4}$ it is suggested a structure where the $\mathrm{Cu}$ (II) ions keep linked by two bridge acetate groups and each $\mathrm{Cu}(\mathrm{II})$ ion maintains coordinated to an acetate group with a monocoordination, moreover, two coordinated orotic acid though oxygen from $\mathrm{C}(2)=\mathrm{O}$ group (see Fig. 6).
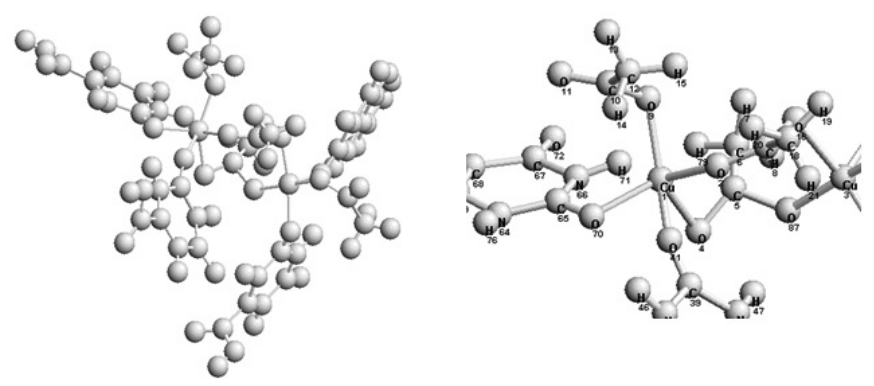

Fig. 6 PM3 structure of $\mathrm{Cu}_{2}\left(\mathrm{CH}_{3} \mathrm{COO}\right)_{4}\left(\mathrm{H}_{3} \mathrm{OR}\right)_{4}$ 
Table 6.Selected PM3 structural parameters of $\mathrm{Cu}_{2}\left(\mathrm{CH}_{3} \mathrm{COO}\right)_{4} \cdot 2 \mathrm{H}_{2} \mathrm{O}$, $\mathrm{H}_{3} \mathrm{OR}, \mathrm{Cu}_{2}$ (acetate $)_{4}\left(\mathrm{H}_{3} \mathrm{OR}\right)_{4}$

\begin{tabular}{|c|c|c|c|}
\hline Parameter & $\mathrm{Cu}_{2}$ (acetate $)_{4}\left(\mathrm{H}_{3} \mathrm{OR}\right)_{4}$ & $\mathrm{Cu}_{2}\left(\mathrm{CH}_{3} \mathrm{COO}\right)_{4} \cdot 2 \mathrm{H}_{2} \mathrm{O}$ & $\mathrm{H}_{3} \mathrm{OR}$ \\
\hline \multicolumn{4}{|l|}{ Bond length $\left(A^{\circ}\right)$} \\
\hline $\mathrm{Cu}(1)-\mathrm{Cu}(3)$ & 4.230 & 3.38 & \\
\hline $\mathrm{Cu}(1)-\mathrm{O}(4)$ & 1.936 & 2.013 & \\
\hline $\mathrm{Cu}(1)-\mathrm{O}(2)$ & 2.039 & 2.018 & \\
\hline $\mathrm{Cu}(1)-\mathrm{O}(9)$ & 1.850 & & \\
\hline $\mathrm{Cu}(1)-\mathrm{O}(70)$ & 1.932 & & \\
\hline $\mathrm{Cu}(1)-\mathrm{O}(41)$ & 2.086 & 1.25 & \\
\hline $\mathrm{C}(5)-\mathrm{O}(4)$ & 1.297 & 1.34 & \\
\hline $\mathrm{C}(65)-\mathrm{O}(70)$ & 1.269 & & 1.223 \\
\hline $\mathrm{C}(67)-\mathrm{O}(72)$ & 1.229 & & 1.218 \\
\hline $\mathrm{Cu}(1)-\mathrm{OH}_{2}$ & & 1.98 & \\
\hline \multicolumn{4}{|l|}{ Bond angle $\left({ }^{\circ}\right)$} \\
\hline $\mathrm{O}(4)-\mathrm{C}(5)-\mathrm{O}(87)$ & 105 & 130 & \\
\hline \multicolumn{4}{|c|}{ Net charge atom $\left(N^{\circ}\right)$} \\
\hline $\mathrm{Cu}(1)$ & -0.315 & -0.212 & \\
\hline $\mathrm{O}(2)$ & -0.206 & -0.241 & \\
\hline $\mathrm{O}(4)$ & -0.236 & -0.251 & \\
\hline $\mathrm{O}(9)$ & -0.371 & & \\
\hline$O(70)$ & -0.172 & & -0.374 \\
\hline $\mathrm{O}(72)$ & -0.334 & & -0.328 \\
\hline
\end{tabular}

In this compound, the distance $\mathrm{Cu}-\mathrm{Cu}, 4.23 \mathrm{~A}^{\circ}$, is higher than that the reported for $\mathrm{Cu}(\mathrm{II})$ acetate monohydrate $3.38 \mathrm{~A}^{\circ}$. $\mathrm{C}=\mathrm{O}$ distances of orotic acid in the complex are higher than that for free acid. For $\mathrm{Cu}(\mathrm{II})$ acetate monohydrate the distance is $1.98 \mathrm{~A}^{\mathrm{o}}$ and those $\mathrm{Cu}-\mathrm{ORH}, \mathrm{Cu}(1)-\mathrm{O}(70)$ are de $1.932 \mathrm{~A}^{\mathrm{o}}$. Important changes of the net charge distribution are observed (see Table 6).

\section{CONCLUSIONS}

In these compounds, both $\mathrm{Cu}(\mathrm{II})$ ions are bound through the acetate group bridge but at an enough distance to present a higher magnetic moments than that the reported for copper(II) acetate monohydrate.

PM3 calculations suggested that the anion orotate coordinated with $\mathrm{Cu}(\mathrm{II})$ through the carboxylic groups with a bidentate coordination and that in neutral medium the orotic acid coordinated through the exocyclic group at a distance $\mathrm{Cu}-\mathrm{ORH}_{3}$ lower than that $\mathrm{Cu}-\mathrm{OH}_{2}$.

\section{ACKNOWLEDGEMENTS}

The authors thank the Dirección de Investigación, Universidad de Concepción (Grant No 206.021.023-1.0). B.L. Rivas thanks to CIPA.

\section{REFERENCES}

1. O.K. Yesilel, H. Ölmez, Transition Metal Chem. 30, 992 (2005).

2. S.L. James, D.M.P. Mingos, X. Xu, A.J.P. White, D.J. Williams, J. Chem. Soc. Dalton Trans., 1335 (1998)

3. G. Maistralis, A. Koutsodimou, N. Katsaros, Transition Metal Chem. 25, $166(2000)$.

4. D.A. Köse, B. Zümreoglu-Karan, O. Sahin, O. Büyükgüngör, J. Mol. Struct.,789, 147 (2006)

5. P. Arrizabalaga, P. Castan, F. Dahan, Inorg. Chem., 22, 2245 (1983)

6. I. Mutikainen, P. Lumme, Acta Cryst., B36, 2233 (1980).

7. T.T.B. Ha, A.M. Larsonneur-Galibert, P. Castan, J. Jaud, J. Chem. Cryst., 29(5), 565 (1999)

8. H. Uekusa, S. Ohba,Y. Saito, Acta Cryst., C45, 377 (1989)

9. G. Smith, C.H.L. Kennard, K.A. Byriel, Polyhedron, 10(8), 873 (1991)

10. B. Ye, X. Chen, F. Xue, L. Ji, T.C.W. Mak, Inorg. Chim. Acta, 299, 1 (2000)

11. B. Kozlevcar, I. Leban, I. Turel, P. Segedin, M. Petric, F. Pohleven, A.J.P. White, D.J. Williams, J. Sieler, Polyhedron, 18, 755 (1999).

12. M.R. Sundberg, R. Uggla and M. Melnic, Polyhedron, 15(7), 1157 (1996).

13. H.A. Henriksson, Acta Cryst., B33, 1947 (1977).

14. L. Abuhijleh, Inorg. Chim. Acta, 194, 9 (1992).

15. L. Abuhijleh, Polyhedron, 15, 285 (1996).

16. G.V. Seguel, B.L. Rivas, C. Novas, J. Chil. Chem. Soc., 51(1) 401 (2005).

17. G.V. Seguel, B.L. Rivas, C. Novas, J. Chil. Chem. Soc., 51(1) 801 (2006).

18. G.V. Seguel, B.L. Rivas, Y. Moreno, O. Peña, Transition Metal Chem. 32, $1106(2007)$.

19. M. Kato, H.B. Jonassen, J. Fanning, Chem. Rev., 64, 99 1964).

20. B.N. Figgis, R.L. Martin, J. Chem. Soc., 3837 (1956).

21. J.V. Bellini, R. Machado, M.R. Morelli, R.H.G.A. Kiminani, Mat. Res. 5(4), 453 (2002).

22. B.L. Rivas, G.V. Seguel, Polyhedron, 18, 2511, (1999).

23. G.V. Seguel, B.L. Rivas, C. Paredes, J. Chil. Chem. Soc.,55(1) 5 (2010).

24. F. Takusagawa, A. Shimado, Bull. Chem. Soc. Jpn., 46, 2011, (1973). 